\title{
Epidemiology Survey of Measles in Kazakhstan
}

\author{
Aygerim Zhuzzhasarova ${ }^{1,2}\left(\mathbb{D}\right.$, Dinagul Baesheva ${ }^{1,2}(\mathbb{D})$, Bayan Turdalina ${ }^{1,2}\left(\mathbb{D}\right.$, Aliya Seidullaeva ${ }^{1,2}$ (D), Alena Altynbekova ${ }^{1,2}$, \\ Madiyar Nurgaziev ${ }^{4,5}$, Bakhytzhan Abdullaev ${ }^{3}$, Almagul Kushugulova ${ }^{4,5}$ (D) \\ ${ }^{1}$ Department of Pediatric Infectious Diseases, Medical University of Astana, Nur-Sultan, Kazakhstan; ${ }^{2}$ Department of Pediatric \\ Infectious Diseases, №3 Multidisciplinary City Children's Hospital, Nur-Sultan, Kazakhstan; ${ }^{3}$ City Multidisciplinary Hospital № 1, \\ Nur-Sultan, Kazakhstan; ${ }^{4}$ Laboratory of Human Microbiome and Longevity, Centre for Life Sciences, National Laboratory Astana, \\ Nazarbayev University, Nur-Sultan, Kazakhstan; ${ }^{5}$ Kazakhstan Society of Human Microbiome Researchers, Nur-Sultan, Kazakhstan
}

Edited by: Ksenija Bogoeva-Kostovska Citation: Zhuzzhasarova A, Bayesheva D, Turdalina B, Kushugulova A, Madiyar Nurgaziev, Bakhytzhan
Kunallan Measles in Kazakhstan. Open Access Maced J Med Sci. 2021 Jul 21; 9(B):704-710 https://doi.org/10.3889/oamjms.2021.6542 Keywords: Measles; Vaccine; Children; Epidemiology; Republic of Kazakhstan *Correspondence: Aygerim Zhuzzhasarova, Departmen of Children's Infectious Diseases, Non-profit jointstock company "Medical University of Astana", №3 Kazakhstan. Tel: +77089994889 mail: zhuzzhasarova.a87@gmail.com Received: 08-Apr-2021 Revised: 29-May-202 Accepted: 11-Jul-202 Copyright: @ 2021 Aygerim Zhuzzhasarova, Dinagul Baesheva, Bayan Turdalina, Aliya Seidullaeva, Alena Altynbekova, Madiyar Nurgaziev, Bakhytzhan Abdullaev, Almagul Kushugulov Funding: This research did not receive any financial Competing Interest: The authors have declared that no competing interest exist Open Access: This is an open-access article distribute
under the terms of the Creative Commons AttributionNonCommercial 4.0 International License (CC BY-NC 4.0)

\section{Introduction}

Measles is an acutely infectious viral disease transmitted by airborne droplets (90-99\% contagiousness index) and is one of the main causes of death in unvaccinated children [1], [2], [3], [4], [5], [6]. Researchers have shown that measles is most severe in young children with malnutrition, especially those with Vitamin A deficiency [7], [8], [9], [10], [11], [12] as well as in the presence of an unfavorable premorbid background [11].

The World Health Organization (WHO) recommends immunization of all susceptible individuals, both children and adults, who have no contraindications for measles immunization. Administration of two doses of the measles vaccine to all children should be the standard for all national immunization programs [13]. A measles vaccine that began in 1963 [14] led to an $80 \%$ reduction in measles mortality between 2000 and 2017 worldwide [13]. Despite significant progress in measles control, outbreaks were reported in various
European countries in 2010 and 2011. For example, in the Republic of Macedonia, 908 cases were registered during this period [15], in Bulgaria, 24,364 cases were registered from 2009 to 2011 [16]. In 2016, 7 million people were infected with measles worldwide. In addition, from 2000 to 2016, the annual reported incidence of measles decreased by $87 \%$, while global measles deaths decreased by 84 [17]. In 2017, approximately $85 \%$ of the world's children received one dose of measles vaccine, while in 2000, vaccination coverage was $72 \%$ [13]. Despite the availability of a safe and cost-effective vaccine, due to the low coverage of the population (85\%) in $2017,110,000$ deaths from measles were recorded in worldwide, primarily among children under the age of 5 . Before the measles vaccine was introduced in 1963, epidemics occurred approximately every 2-3 years, and 2.6 million people died of measles every year [14].

Depending on the geographical location and seasonality, the manifestations of measles can mimic the clinical picture of other viral diseases. Moreover, in 
people with weakened immunity, this infection may not cause the typical symptoms of measles, which is often accompanied by severe disease outcomes, especially the development of measles pneumonia and encephalitis [18], [19], [20]. Thus, the current measles elimination targets in all countries require surveillance of every case, including laboratory confirmation of suspected cases [21].

\section{Methods}

We analyzed statistical data of the Committee for the Protection of Public Health on the incidence of measles in the Republic of Kazakhstan for the period of November 1, 2018-December 30, 2019.

\section{Results}

The introduction and spread of measles in the Republic of Kazakhstan were facilitated by the global complication of the epidemiological situation around the world, including in Europe. Measles incidence monitoring shows that in European countries, the number of measles cases reached a high level in 2018 , when 83,540 cases of measles and 74 deaths from it were registered in Europe. In Serbia and North Kosovo, from October 2017 to August 2019, there were 5798 cases of measles and 15 deaths in Bosnia and Herzegovina, 1489 cases of measles were reported in 2018 and 2019, while in North Macedonia, 1948 cases were reported in 2018 and 2019, Croatia had 16 cases of 19, and Greece had 3150 cases of measles [22]. The report of the WHO announced the regions where there was an increase in measles: The regions of the East Mediterranean, Europe, and America, in areas where the elimination of measles has been declared or is close to elimination. The resurgence of measles may indicate a gap in previous vaccination strategies. According to the latest WHO-UNICEF report, only five European countries reported $>95 \%$ vaccination coverage with both doses of measles vaccine; the corresponding figures in Greece for the first and second doses were 97-99\% and 77-83\% between 2008 and 2018. Although the epidemic was contained in Greece in 2019, there was a significant increase in other European countries in the same year, with a total of 13,460 cases. Similarly, an outbreak with 1282 cases was reported in the United States of America during 2019, a country that declared measles elimination in 2000 [23].

Figure 1 shows the total incidence of measles in the Republic of Kazakhstan from 1998 to 2019. According to the data presented, the largest increase in incidence for the entire study period is noted in 2004, during which time the indicator was $106.4 \%(n=16118)$. In connection with the additional immunization performed in 2005-2006, a decrease in the incidence rate to $0.71 \%$ was noted in 2006 .

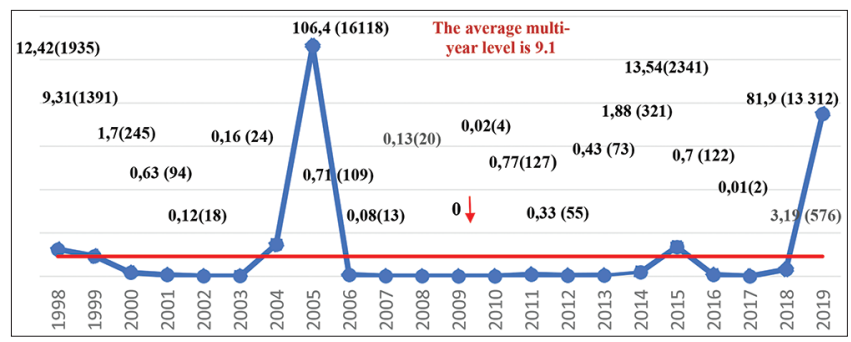

Figure 1: The long-term incidence of measles in the Republic of Kazakhstan

Epidemiological surveillance of measles in the Republic of Kazakhstan was carried out on passively registered cases and during routine surveillance. The time period from 2006 to 2014 is characterized by a period of well-being, in which the rate of registered patients ranged from $0.7 \%$ to $1 \%$. The year 2015 was characterized by an increase in the incidence of measles, where the overall rate was $13.54 \%(n=2341)$; against the background of increased immunization, a decrease was observed in cases from $3.1 \%$ to $0.7 \%$ between 2016 and 2018 followed by a further increase in incidence rates between 2018 and 2019 to $81.9 \%$ ( $n=13,312)$.

Monitoring of the disease in the Republic of Kazakhstan indicates that the incidence of measles from November 2018 to December 30, 2019, amounted to 13,873 cases, of which $71.2 \%(n=9875)$ affected children aged 6 months-14 years. In the cartogram (Figure 2), the incidence of outbreaks in four regions of the country where the number of cases exceeded 1000 patients is shown: Nur-Sultan $-22.9 \%(n=3181)$, Shymkent - 22.3\% ( $n=3095)$, Mangistau - 10.3\% $(n=1428)$, and in the Turkestan region $-8 \%(n=1110)$. The following regions had a number of measles cases ranging from 200 to 1000: Atyrau, Almaty, Kyzylorda, Karaganda, Zhambyl, Akmola, Aktobe, the North Kazakhstan region, the Pavlodar region, and Almaty city; up to 200 cases of the disease were registered in Kostanay as well as in the West Kazakhstan and East Kazakhstan regions.

Most of the measles patients were young children, but all age groups, including adults, were affected to varying degrees. Since the beginning of the current measles outbreak, there is no seasonal pattern of the disease circulating all year round, with a large number of cases reported even in the summer.

The total number of measles cases in the Republic of Kazakhstan in 2018 amounted to 576 cases, of which $84 \%$ were children and $16 \%$ were adults. In 2019 , the total number of measles cases increased by 23 -fold compared to that in 2018 and amounted to 13,297 cases. Changes in the age structure are noteworthy, since in 2019 , the number of sick children 


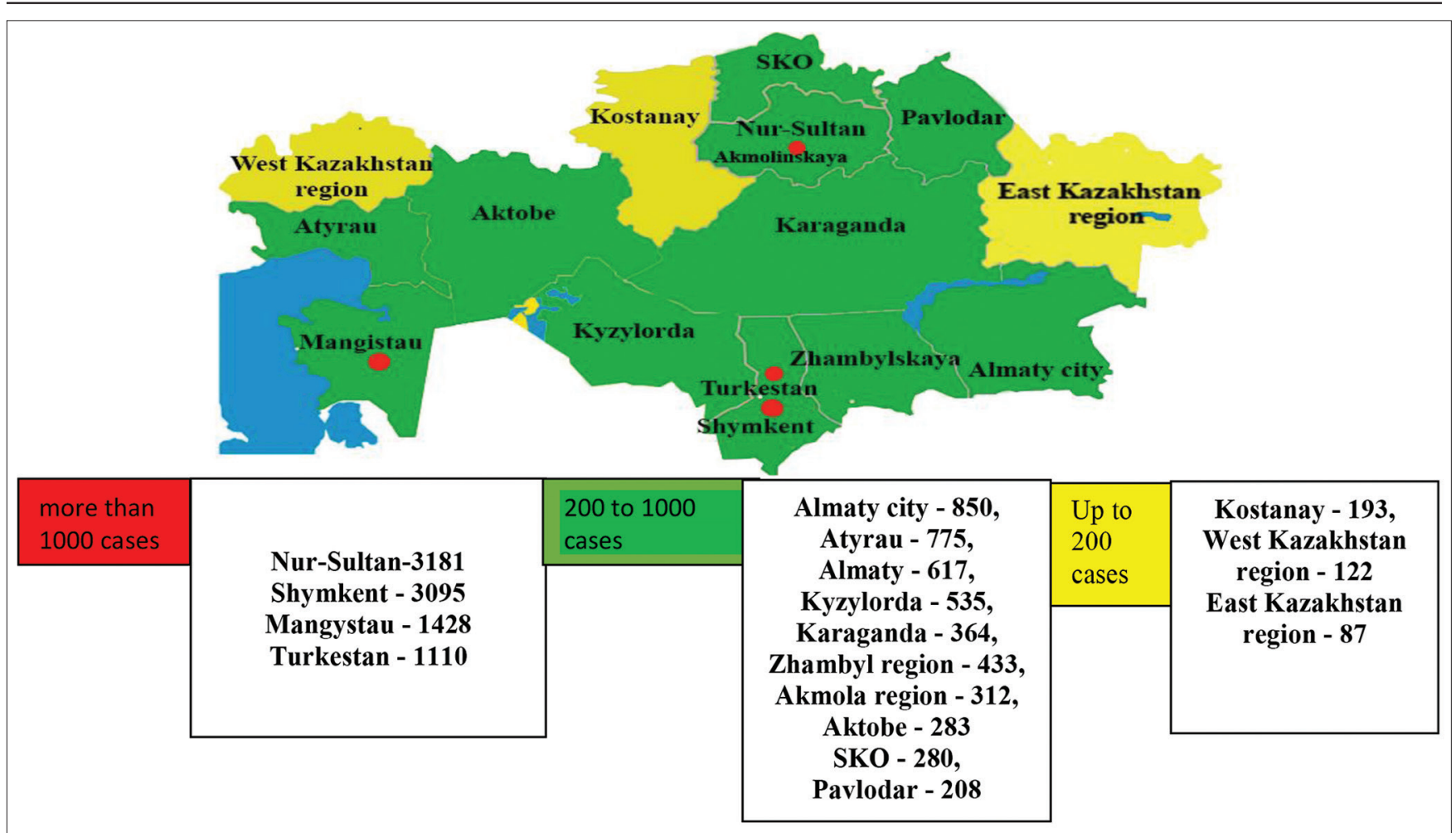

Figure 2: Monitoring of measles incidence in the Republic of Kazakhstan from November 2018 to December 30, 2019

decreased from $84 \%$ to $71 \%$, but the incidence rates in adults increased from $16 \%$ to $29 \%$ (Figure 3).

For the regional distribution of measles incidence rates in 2018, the highest incidence in terms of the total number of cases was noted in Nur-Sultan $(72.7 \% ; n=419)$, Almaty (9.7\%; $n=56)$, Akmola Oblast $(5.6 \% ; n=32)$, Turkestan Oblast $(3.5 \% ; n=20)$, and Almaty Oblast $(2.1 \% ; n=12)$.

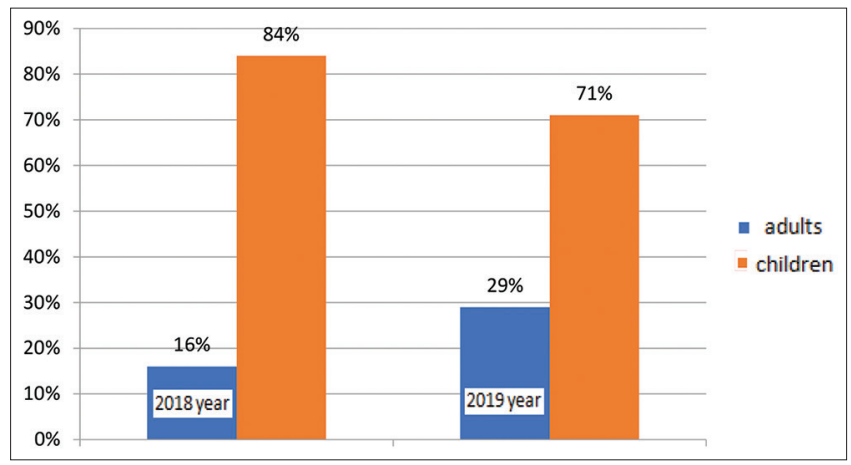

Figure 3: The incidence of measles in the Republic of Kazakhstan in 2018 and 2019

In 2019, these incidence rates, both in the regions and in the cities of Nur-Sultan and Almaty, increased significantly. For example, in the city of NurSultan, the absolute indicators of the total number of cases amounted to 2762 compared to 419 , that is, the number of cases increased 6.6-fold, while the relative indicators, in contrast, decreased from $73 \%$ to $20.8 \%$. In Almaty, despite the decrease in the relative disease rates from $9.7 \%$ to $6 \%$, the absolute number of sick patients also tended to increase, amounting to 794 versus 56, indicating an increase in the number of measles patients in the metropolis of 14.2-fold. In the Akmola region, the number of cases of the disease in absolute terms was characterized by a substantial increase to 280 from 32 , which indicates an increase in the disease incidence of 8.8-fold, and there was also a tendency for the disease relative indicator to increase $(5.6 \%$ vs. $2.1 \%)$ by 3.5 fold. In the Turkestan region, there was an increase in both the relative (4.7-fold; $3.5 \%$ vs. $8.2 \%$ ) and absolute indicators (54.5-fold; 1090 vs. 20), which indicates an outbreak of the disease in this region. In the Zhambyl region, the increase in absolute numbers was 429 versus 4 , and the relative indicator was $3.2 \%$ versus $0.7 \%$, which indicates an increase in the relative indicator of 2.5-fold. In the North Kazakhstan region, there is an increase in the number of both absolute (279 vs. 1) and relative indicators of 1.9 -fold $(2.1 \%$ vs. $0.2 \%)$.

In 2019, in the Almaty region, there was a 2-fold increase in the relative incidence of measles (4.5\% vs. $2.1 \%$ ) and an increase in absolute indicators of $50.4-$ fold (605 vs. 12). In the Mangistau region, there was an increase in the absolute incidence rates of 237-fold (1422 vs. 6$)$ and in the relative rates of 10 -fold $(10.8 \%$ vs. $1 \%$ ). In the Karaganda region, the absolute number of measles cases increased 23.2-fold (349 vs. 15), and the relative indicator increased by $2.6 \%$.

The following regions reported no measles cases in 2018: Atyrau, West Kazakhstan, Kostanai, and Kyzylorda; in 2019, the number of registered cases in these regions was as follows: Atyrau (5.8\%; $n=775)$, West Kazakhstan (0.9\%; $n=122)$, in Kostanay $(1.5 \%$; $\mathrm{n}=193)$, and Kyzylorda (4\%; $n=525)$, indicating the spread of the virus to other areas of the country. 
Thus, the comparative assessment of the absolute and relative indicators of measles incidence in the country was characterized by the intensive spread of the measles virus to all regions of the Republic of Kazakhstan (Figure 4).

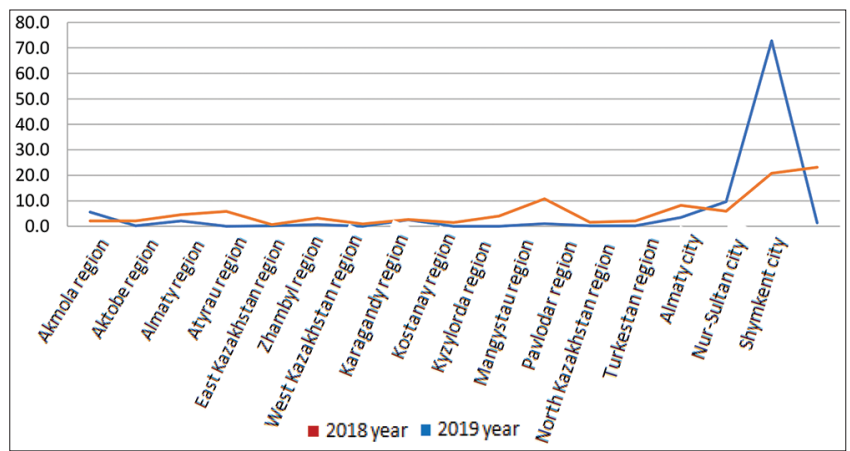

Figure 4: The incidence of measles in the regions of the Republic of Kazakhstan in 2018 and 2019

As mentioned earlier, the incidence of measles from November 2018 to December 30, 2019, resulted in 13,873 cases, of which $71.2 \%(n=9875)$ affected children aged 6 months-14 years. Given that measles primarily occurs in children, we conducted a thorough analysis of the age and gender of children aged 6 months -1 year who were infected, since it is known that maternal immunity should be conveyed to this demographic.

The age and gender of measles patients from 0 months to 11 months. Among measles cases, children under 1 year old made up $41.8 \%(n=4128)$ of cases. Among these, children from 0 months to 6 months amounted to $34.1 \%(n=1409)$, children from 7 months to 8 months amounted to $28.4 \%(n=1171)$, and children from 9 months to 11 months amounted to $37.5 \%(n=1548)$ (Figure 5$)$.

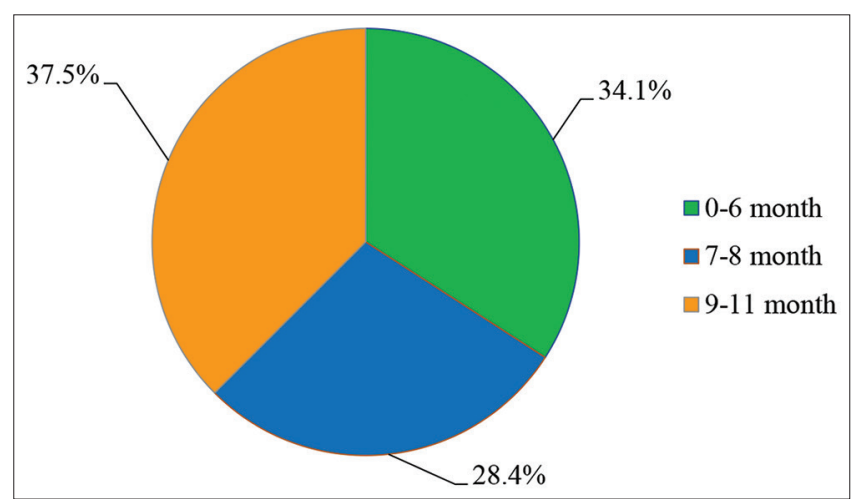

Figure 5: Age characteristics of children from 6 months to 1 year with measles in the Republic of Kazakhstan

The data obtained revealed that among infected patients, a greater number of cases occurred between the ages of 1 and 14 years, which amounted to $58.2 \%(\mathrm{n}=5745)$ of total cases. Among these, children aged 1 year amounted to $38.5 \%(n=2213)$. It should be assumed that the reason for the increase in the number of children during the $1^{\text {st }}$ year of life was a lack of passive immunity, since it is possible that the mothers of these children did not have measles or were not vaccinated in the late 80 s or early 90 s [10]. Children at 2 years old made up $18.7 \%(n=1075)$, at 3 years old made up $12.3 \%(n=708)$, at 4 years old made up $8.3 \%$ $(n=479)$, and at 5 years old made up $5.4 \%(n=308)$ of the patient population. Notably, children undergo measles revaccination at 6 years old; accordingly, we observed that the incidence of measles decreases based on this age, so the number of sick children at 6 years old was $3.9 \%(n=226)$, at 7 years old was $3.1 \%$ $(n=179)$, at 8 years old was $1.8 \%(n=103)$, and from 10 years to 14 years was $5.9 \%(n=341)$ (Figure 6$)$.

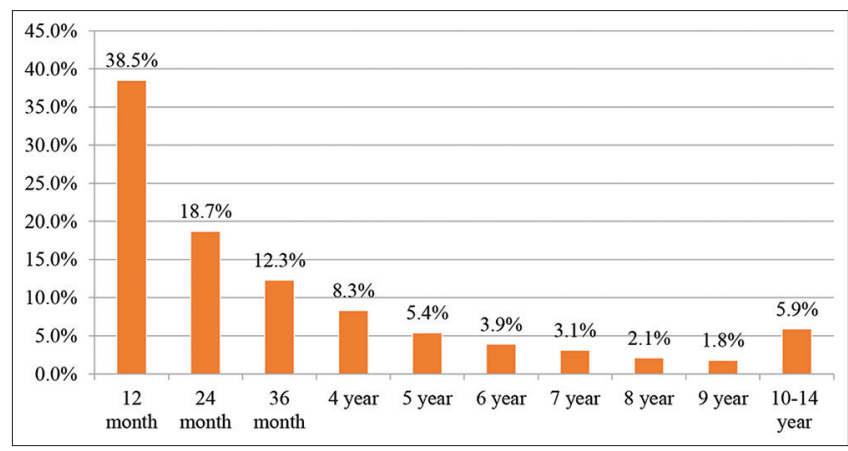

Figure 6: Age characteristics of children from 1 to 14 years with measles in the Republic of Kazakhstan

The gender of children aged 0 month-11 months who became infected with measles indicates that among children from 0 to 6 months, boys accounted for $32.2 \%$ $(n=761)$ of cases, and girls made up $36.7 \%(n=648)$ of cases. At the age of $7-8$ months, boys made up $28.9 \%$ $(n=684)$ and girls $27.6 \%(487)$ of the population. At the age of 9 months -11 months, boys made up $38.9 \%$ ( $n=$ 919 ) and girls $-35.7 \%$ (629) of total cases (Figure 7).

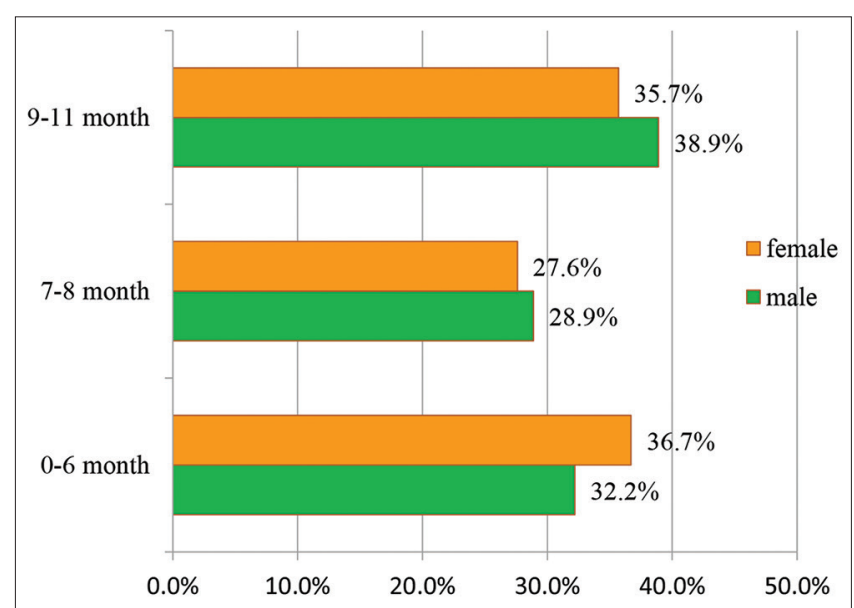

Figure 7: Gender characteristics of children from 6 months to 1 year with measles in the Republic of Kazakhstan

An analysis of gender characteristics from the age of 1-14 years showed the following results: At 1 year, boys with measles accounted for $39.9 \%(n=1310)$ of infections and girls accounted for $36.8 \%(n=903)$; at 2 years of age, boys comprised $18 \%(n=593)$ of patients and girls $19.6 \%(n=482)$; at 3 years old, boys made up $11.9 \%(n=391)$ of cases and girls $12.9 \%(n=317)$; at 4 years old, boys were $8.3 \%(n=274)$ of infections and girls were $8.3 \%$ (205); at 5 years old, boys exhibited 
$5.3 \%(173)$ of infections and girls 5.5\% ( $n=135)$; at 6 years, boys accounted for $3.5 \%(n=116)$ of cases and girls for $4.5 \%$ (110); at 7 years old, boys comprised $3.1 \%$ $(n=101)$ of cases and girls $3.2 \%(n=78)$; at 8 years, boys made up $1.9 \%(n=62)$ of infections and girls $2 \%$ ( $n$ $=50)$; at 9 years old, boys represented $1.7 \%(n=57)$ of cases and girls $1.9 \%(n=46)$; and from 10 to 14 years old, boys accounted for $6.4 \%(n=210)$ of infections and girls for $5.3 \%(n=131)$ (Figure 8$)$. Studying the gender characteristics of children with measles, we found that male children are more susceptible to the measles virus, which confirms a the results of a previous study by the scientists Klein SL1, Marriott 12, and Fish EN3 that revealed that a higher development of antibodies to the introduced virus occurs in women compared to men. In the investigators' opinion, the development of vaccines should be gender specific to reduce adverse reactions in women and increase immunogenicity in men [24].

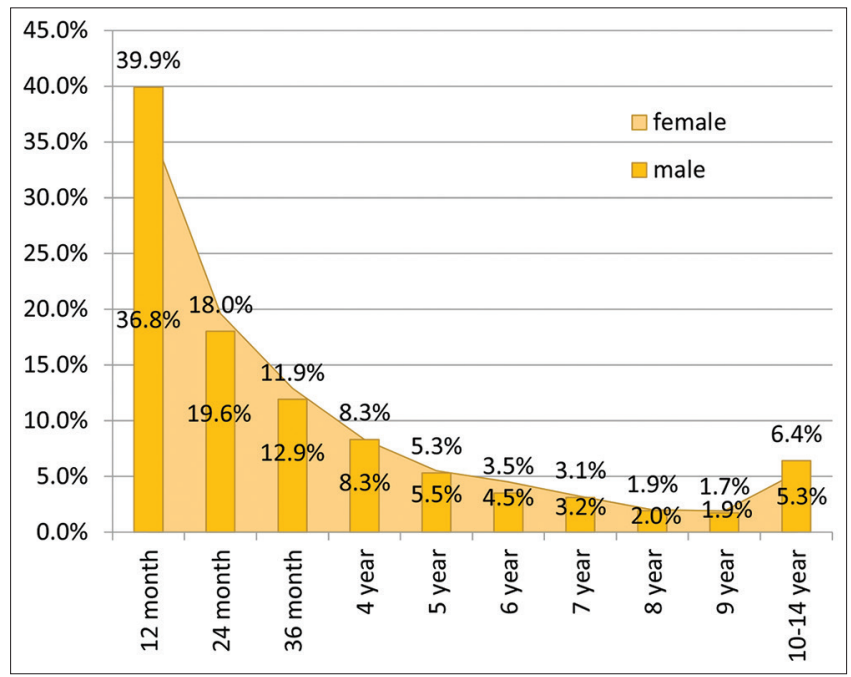

Figure 8: Gender characteristics of children from 1 to 14 years with measles in the Republic of Kazakhstan

The WHO currently considers vaccination one of the most effective and cost-effective means of fighting infections. The use of vaccines is recognized as a key element of a country's epidemic well-being [25].

To analyze the relationship between measles incidence and vaccination, we examined immunization coverage data for children with measles from November 2018 to December 2019.

The total number of sick children aged 0 month-11 months was $41.8 \%$. We studied the vaccination coverage of these children in detail and observed that from the age of 0 month to 8 months, children did not receive the MMR vaccine, since the first dose of the vaccine is administered at 9 months, while children receive the second dose of the vaccine at 6 years old. Twenty-five children aged 9-11 months received the first dose of MMR vaccine.

The number of sick children aged 1-14 years was $58.2 \%$. Indicator of the vaccination status of children with measles up to 1 year old did not receive the vaccine for various reasons, and children from
1 year to 14 years old were not vaccinated with the MMR vaccine in $49.8 \%$ of cases (Table 1 ).

Table 1: Vaccination coverage for children with measles between the ages of 0 month and 14 years

\begin{tabular}{|c|c|c|c|c|c|}
\hline \multirow[t]{3}{*}{ Age } & \multicolumn{5}{|c|}{ Vaccination status } \\
\hline & \multirow[t]{2}{*}{$\begin{array}{l}\text { Total } \\
\text { vaccinated, } \mathrm{n}\end{array}$} & \multicolumn{2}{|c|}{$\begin{array}{l}\text { Of them are } \\
\text { vaccinated }\end{array}$} & \multirow[t]{2}{*}{$\begin{array}{l}\text { Total } \\
\text { unvaccinated, } \mathrm{n}\end{array}$} & \multirow[t]{2}{*}{$\%$} \\
\hline & & 1-fold, $\mathrm{n}$ & 2-fold, $\mathrm{n}$ & & \\
\hline $0-6$ months & 0 & 0 & 0 & 1409 & 34.4 \\
\hline $7-8$ months & 0 & 0 & 0 & 1171 & 28.6 \\
\hline 9-11 months & 25 & 25 & 0 & 1518 & 37.0 \\
\hline Up to 1 year & 25 & 25 & 0 & 4098 & 50.2 \\
\hline 1 year & 255 & 255 & 0 & 1889 & 46.4 \\
\hline 2 years & 269 & 269 & 0 & 770 & 18.9 \\
\hline 3 years & 210 & 210 & 0 & 475 & 11.7 \\
\hline 4 years & 169 & 169 & 0 & 294 & 7.2 \\
\hline 5 years & 91 & 89 & 2 & 205 & 5.0 \\
\hline 6 years & 67 & 45 & 22 & 147 & 3.6 \\
\hline 7 years & 66 & 27 & 39 & 107 & 2.6 \\
\hline 8 years & 51 & 18 & 33 & 59 & 1.4 \\
\hline 9 years & 59 & 16 & 43 & 41 & 1.0 \\
\hline $10-14$ years & 245 & 38 & 207 & 85 & 2.1 \\
\hline From 1 year to 14 years & 1482 & 1136 & 346 & 4072 & 49.8 \\
\hline
\end{tabular}

\section{Measures to control the outbreak}

Since April 1, 2019, an additional program of population immunization has been launched in the Republic of Kazakhstan. The vaccination program includes children who have reached the age of 9 months, persons under the age of 30 with an unknown vaccination status, those who have not previously been vaccinated and have not had measles, those who were vaccinated 5 or more years ago with a single measles vaccine in the foci of infection, as well as medical workers. Throughout the rise of the disease, health workers were offered a dose of the CCP vaccine, regardless of their immunization status or age.

To vaccinate the population, special groups were deployed for the work of the supplementary immunization program, consisting of epidemiologists and infectious disease doctors, as well as general practitioners.

To raise awareness of the population and medical professionals about the incidence of measles in the Republic of Kazakhstan, events were held among these groups. Timely information was provided on the increase in the incidence of the population and information was provided on surveillance activities and on the work of immunization through the press release of the Ministry of Health of the Republic of Kazakhstan. Information packages, including a description of measles, an update on the status of the outbreak, and a call for the population to be vaccinated, were sent to the media.

\section{Discussion}

In our study, we assessed the nature of the measles outbreak between November 2018 and December 2019. Where it was revealed that in 2019, the total number of cases of measles increased by 
23 times $(n=13297)$ compared to 2018 . The magnitude of the outbreak highlighted a significant number of susceptible children and amounted to $71.2 \%(n=9875)$. The age structure of measles patients was dominated by children aged $1-14$ years $(50.2 \%)$.

Since primary vaccine inefficiency is described to occur in $2-5 \%$ of vaccinated children after the first dose of the vaccine administered at 12 months of age, the accumulation of people who did not respond to the first dose of RCT probably also contributed to the pool of susceptible children [16], [26]. It is worth noting that infected adults can transmit the measles virus to susceptible children. Moreover, susceptible mothers are unable to transmit protective antibodies against the measles virus to newborns, making them vulnerable to possible measles infection by their parents or other loved ones [27]. Our study found that more than half of the children's population in the Republic of Kazakhstan were not vaccinated or received only one dose of the MMR vaccine, which indicates that they either refused vaccination or missed various opportunities to receive the vaccine allocated by the state. During this outbreak, measles transmission occurred in several medical institutions, so cases of children with cancer were recorded. This requires clear recommendations on how to comply with infection control measures in health-care facilities and ensure that health workers and patients with background diseases are adequately protected. The measles outbreak has reminded all countries in the WHO European region of their commitments to eliminate measles. To achieve this goal, each country needs to ensure high immunization coverage $(>95 \%)$ with two doses of MMR. When coverage falls below this threshold, the risk of measles outbreaks or epidemics increases exponentially [28].

The aim of this study was to investigate the clinical, gender, and age characteristics of measles during the rise in the incidence of measles among children in the Republic of Kazakhstan.

\section{Conclusion}

Measles remains an unresolved global problem, and groups of undervaccinated or unvaccinated populations remain vulnerable during epidemics. Therefore, due to the increase in the non-immune part of the population due to refusals of vaccination for various reasons, at the present stage, the levels of indicators of vaccine-controlled infections are increasing. Measles in the Republic of Kazakhstan needs further study, including the reasons for refusal of vaccination, to conduct training on the safety of vaccines and eliminate false contraindications, both among medical professionals and among the general public, to increase the level of collective immunity.

\section{Acknowledgments}

We express our gratitude to the staff of branch "Scientific and Practical Center of Sanitary and Epidemiological Expertise and Monitoring" of the National Health Service for providing reliable information on the incidence of measles among the population of the Republic of Kazakhstan.

\section{Ethical Approval}

Approval of the ethics Commission is not required, as in this study, we analyzed the incidence of measles in the population of the Republic of Kazakhstan for 2018-2019 during the rise of the disease.

\section{Data Availability}

ht t p: //ww w.rcrz.kz/index.php/ru/ statistika-zdravookhraneniya-2.

\section{References}

1. Strebel PM, Orenstein WA. Measles. $\mathrm{N}$ Engl J Med. 2019;381(4):349-57.

PMid:31184814

2. World Health Organization. Global Measles and Rubella Strategic Plan: 2012-2020. Geneva, Switzerland: World Health Organization; 2012.

3. Shanks GD, Hu Z, Waller M, Lee SE, Terfa D, Howard A, et al Measles epidemics of variable lethality in the early $20^{\text {th }}$ century. Am J Epidemiol. 2014;179(4):413-22. https://doi.org/10.1093/ aje/kwt282 PMid:24284015

4. Porter A, Goldfarb J. Measles: A dangerous vaccine-preventable disease returns. Cleve Clin J Med. 2019;86(6):393-8. https://doi. org/10.3949/ccjm.86a.19065 PMid:31204978

5. World Health Organization. Warns that Progress towards Eliminating Measles has Stalled. Geneva: World Health Organization; 2017. Available from: https://www.who.int/ mediacentre/news/releases/2014/eliminating-measles/en. [Last accessed on 2017 Apr 05]

6. Gans HA, Maldonado Y, Yasukawa LL, Beeler J, Audet S, Rinki MM, et al. IL-12, IFN-gamma, and T cell proliferation to measles in immunized infants. J Immunol. 1999;162(9):5569-75. PMid:10228039

7. Campos-Outcalt D. Measles: Why it's still a threat. J Fam Pract. 2017;66(7):446-9.

PMid:28700761 
8. Lindberg C, Lanzi M, Lindberg K. Measles: Still a significant health threat. MCNAm J Matern Child Nurs. 2015;40(5):298-305; quiz E21-2. https://doi.org/10.1097/nmc.0000000000000162 PMid:26110575

9. D'Souza RM, D'Souza R. Vitamin A for treating measles in children. Cochrane Database Syst Rev. 2001;2:CD001479. https://doi.org/10.1002/14651858.cd001479 PMid:11405993

10. Bello S, Meremikwu MM, Ejemot-Nwadiaro RI, Oduwole O. Routine VitaminAsupplementation for the prevention of blindness due to measles infection in children. Cochrane Database Syst Rev. 2014;1:CD007719. https://doi.org/10.1002/14651858. cd007719.pub3 PMid:21491401

11. Bichon A, Aubry C, Benarous L, Drouet H, Zandotti C, Parola P, et al. Case report: Ribavirin and Vitamin $A$ in a severe case of measles. Medicine. 2017;96(50):e9154. https://doi.org/10.1097/ md.0000000000009154 PMid:29390321

12. Moss WJ, Griffin DE. Measles. Lancet. 2012;379(9811):153-64. PMid:21855993

13. Imdad A, Herzer K, Mayo-Wilson E, Yakoob MY, Bhutta ZA. Vitamin A supplementation for preventing morbidity and mortality in children six months to five years of age. Cochrane Database Syst Rev. 2010;3(3):CD008524. https://doi. org/10.1002/14651858.cd008524 PMid:28282701

14. Patel MK, Gacic-Dobo M, Strebel PM, Dabbagh A, Mulders MN, Okwo-Bele JM, et al. Progress toward regional measles elimination worldwide, 2000-2015. Morb Mortal Wkly Rep. 2016;65(44):122833. https://doi.org/10.15585/mmwr.mm6544a6 PMid:27832050

15. Kondova IT, Milenkovic Z, Marinkovic SP, Bosevska G, Kuzmanovska G, Kondov G, et al. Measles outbreak in Macedonia: Epidemiological, clinical and laboratory findings and identification of susceptible cohorts. PLoS One. 2013;8(9):e74754. https://doi.org/10.1371/journal. pone. 0074754

PMid:24040337

16. Muscat M, Marinova L, Mankertz A, Gatcheva N, Mihneva Z, Santibanez S, et al. The measles outbreak in Bulgaria, 20092011: An epidemiological assessment and lessons learnt. Euro Surveill. 2016;21(9):30152. https://doi.org/10.2807/1560-7917. es.2016.21.9.30152

PMid:26967661

17. Ristic M, Milosevic V, Medic S, Malbasa JD, Rajcevic S, Boban J, et al. Sero-epidemiological study in prediction of the risk groups for measles outbreaks in Vojvodina, Serbia. PLoS One. 2019;14(5):e0216219. https://doi.org/10.1371/journal. pone.0216219

PMid:31071124

18. McCarthy M. US sees first measles death in 12 years. BMJ. 2015;351:h3653. https://doi.org/10.1136/bmj.h3653
PMid:26141853

19. Wyplosz B, Lafarge M, Escaut L, Stern JB. Fatal measles pneumonitis during Hodgkin's lymphoma. BMJ Case Rep. 2013;2013:bcr2013200252. https://doi.org/10.1136/ bcr-2013-200252

PMid:24105383

20. Liu Y, Sun LY, Zhu ZJ, Lin W, Qu W, Zeng ZG. Measles virus infection in pediatric liver transplantation recipients. Transpl Proc. 2015;47(9):2715-8. https://doi.org/10.1016/j. transproceed.2015.07.030

PMid:26680079

21. Rota PA, Moss WJ, Takeda M, de Swart RL, Thompson KM, Goodson JL. Measles. Nat Rev Dis Primers. 2016;2:16049. https://doi.org/10.1038/nrdp.2016.49 PMid:27411684

22. Georgakopoulou T, Horefti E, Vernardaki A, Pogka V, Gkolfinopoulou K, Triantafyllou E, et al. Ongoing measles outbreak in Greece related to the recent European-wide epidemic. Epidemiol Infect. 2018;146(13):1692-8. https://doi. org/10.1017/s0950268818002170

PMid:30086813

23. Fragkou PC, Thomas K, Sympardi S, Liatsos GD, Pirounaki M, Sambatakou $\mathrm{H}$, et al. Clinical characteristics and outcomes of measles outbreak in adults: A multicenter retrospective observational study of 93 hospitalized adults in Greece. J Clin Virol. 2020;131:104608. https://doi.org/10.1016/j. jcv.2020.104608

PMid:32877891

24. Klein SL, Marriott I, Fish EN. Sex-based differences in immune function and responses to vaccination. Trans $\mathrm{R}$ Soc Trop Med Hyg. 2015;109(1):9-15.

PMid:25573105

25. Blakely KK, Suttle R, Wood T, Stallworth K, Baker N. Measles what's old is new again. Nurs Womens Health. 2020;24(1):45-51. https://doi.org/10.1016/j.nwh.2019.11.005 PMid:31917147

26. Medic S, Petrovic V, Loncarevic G, Kanazir M, Lazarevic IB Adrovic SR, et al. Epidemiological, clinical and laboratory characteristics of the measles resurgence in the Republic of Serbia in 2014-2015. PLoS One. 2019;14(10):e0224009. https://doi.org/10.1371/journal.pone.0224009 PMid:31622429

27. Vatev NT, Stoycheva MV, Petrov Al. Reemergence of measles in Bulgaria: A large outbreak in Plovdiv, 2010. Braz J Infect Dis. 2011;15(6):613-6. https://doi.org/10.1590/ s1413-86702011000600021

PMid:22218526

28. Pitigoi D, Sandulescu O, Craciun MD, Draganescu A, Jugulete G, Streinu-Cercel A, et al. Measles in Romania Clinical and epidemiological characteristics of hospitalized measles cases during the first three years of the 2016-ongoing epidemic. Virulence. 2020;11(1):686-94. https://doi.org/10.1080/2150559 4.2020 .1771948

PMid:32507005 